2020, Vol. 9, Issue 2

\title{
Joanna Markiewicz-Stanny
}

Assistant Professor, Department of Jurisprudence, Legal Philosophy

and History of Law, University of Zielona Góra

https://orcid.org/0000-0002-1842-7243

\section{THE RIGHTS OF THE CHILD AND A PROBLEM OF IMMIGRATION DETENTION}

\begin{abstract}
The problem of children immigration detention will be explored based on the analysis of international human rights law and international refugee law. Preliminary remarks will elaborate on how migration detention impacts on the exercise of the rights of the child, focusing, in particular, on the deleterious influence this measure exerts on the child's mental well-being. Next, the principle of using child migration detention as a measure of last resort will be analysed in light of international standards. The practical implementation of this principle calls for observing the standards for individual assessment of the particular situation of each immigrant child. This includes treating the minors first and foremost as children, and only then as immigrants. Another key element is the area of the state's positive obligations. International case law has increasingly called for an absolute obligation to first provide the child or the family with a child with an alternative to the detention measure. This involves the need to establish the necessary infrastructure that would allow for such an alternative solution. Furthermore, in a situation where detention is necessary, it should be exercised while accommodating the needs of families with children. As will be demonstrated, nonfeasance and negligence lead, in the most extreme cases, to their being recognised as violation of the prohibition of inhuman or degrading treatment or punishment.
\end{abstract}

Keywords: immigration detention, right of the child, human rights law 


\section{Introduction}

The title of this work has been worded in such a way as to emphasize the fact that using detention against children interferes with their liberty and security, as well as impacting on their family bonds, emotional wellbeing and psycho-social development. In this light, particular significance should be paid to the child's freedom from torture, inhuman or degrading treatment or punishment, their right to respect for private and family life, right to education and right to have access to proper medical care and treatment. Thus, rather than analysing an isolated type of law, this article offers a look at the problem of migrant detention from the vantage point of the subject - the child.

Eliminating detention of children has become one of the key goals adopted by the UNHCR in the strategy Beyond Detention 2014-2019. ${ }^{1}$ This is a very ambitious undertaking, that, however, is far from completion. Owing to the irregular migration situation in Europe, children of all ages face the risk of detention, which applies to those travelling with parents and unaccompanied children alike. ${ }^{2}$ These are minors seeking international protection, children who have left their country of origin for lack of any decent future prospects, and children who are fleeing exploitation, violence and human trafficking. At the same time, there is a paucity of reliable and comprehensive data on the scale of this phenomenon, which can be attributed to some European states' inability or reluctance to provide statistical data on child detention. ${ }^{3}$

1 UNHCR, Beyond Detention. A global strategy to support governments to end the detention of asylum seekers and refugees, available at: http://www.unhcr.org/53aa929f6. pdf.

Cf. Parliamentary Assembly of the Council of Europe Committee on Migration, Refugees and Displaced Persons A study of immigration detention practices and the use of alternatives to immigration detention of children, Council of Europe Strasbourg 2017, p. 9; Report of the Special Rapporteur on the human rights of migrants, Francois Crépeau: Regional Study: Management of the External Borders of the European Union and its impact on the human rights of migrants, 24.4.2013, A/HRC/23/46, para. 45.

3 Global Detention Project reported that of the 33 European countries it examined, as many as 19 did not disclose the locations of where migrants are detained, 12 did not provide statistics on the total number of migrants detained, and 17 countries did not disclose information on the number of detained asylum seekers. Moreover, Austria, Denmark, Germany, Switzerland and the United Kingdom did not disclose information 
In this work, the term 'detention' is used to mean administrative measures of deprivation of liberty in pursuance of procedures on the entry and residence of aliens in the territory of a state and international protection. Under the UNHCR Guidelines on the Applicable Criteria and Standards relating to the Detention of Asylum Seekers and Alternatives to Detention ('the UNHCR Guidelines'), detention is defined as 'the deprivation of liberty or confinement in a closed place which an asylum-seeker is not permitted to leave at will, including, though not limited to, prisons or purpose-built detention, closed reception or holding centres or facilities'. In practical terms, these places of confinement also include airport transit zones, police stations, basements, quarters used by border guards, watercraft and abandoned factories. At the same time, it must be pointed out that the treatment of detainees is highly diversified in Europe, with marked discrepancies even existing within individual states. These often make for a sharply polarised situation: on the one hand, there are immigrantonly detention centres offering decent conditions of stay and treatment that frequently surpass those in the asylum-seeker's country of origin; on the other, however, migrants are still being detained in prisons or facilities of a similar nature, where living conditions are considered to be below prison-like and basic. ${ }^{5}$ At the far extreme are detention centres that meet the criteria for degrading and inhuman treatment or punishment. ${ }^{6}$

Overall, even when performed in best conditions available, migration detention is, as a matter of fact, a case of deprivation of liberty that leads to some sort of isolation. Its adverse impact is further magnified by the vulnerable situation of the irregular migrant child. ${ }^{7}$ This

on the numbers of minors held in detention - see Uncounted: The Detention of Migrants and Asylum Seekers in Europe, Global Detention Project, 2015, p. 3.

4 UNHCR, Guidelines on the Applicable Criteria and Standards relating to the Detention of Asylum-Seekers and Alternatives to Detention, 2012, p. 9, paras. 5 and 9, http://www. refworld.org/docid/503489533b8.html (accessed: 23.11.2013).

5 See Mahamed Jama v. Malta, Application no. 10290/13, ECtHR Judgment of 26.11.2015, paras. 18-26.

6 See Rahimi v. Greece, Application no. 8687/08, ECtHR Judgment of 5.4.2011, paras. 59-62; Mubilanzila Mayeka, and Kaniki Mitunga v. Belgium, Application no. 13178/03, ECtHR Judgment of 12.10.2006; Muskhadzhiyeva and others v. Belgium, Application no. 41442/07, ECtHR Judgment of 19.1.2010.

7 See Preamble to UN General Assembly Resolution - Protection of Migrants, 24.2.2000, A/RES/54/166; M.S.S. v. Belgium and Greece, Application no. 30696/09, ECtHR Judgment of (Grand Chamber) of 21.11.2011, para. 251. See also P. S. Pinheiro, World Report on violence against children. United Nations Secretary-Generals' Study on Violence 
particularly difficult situation is deemed extremely vulnerable in the case of unaccompanied children and those seeking international protection. ${ }^{8}$ More often than not, detention facilities are guarded by uniformed personnel and surrounded by a high fence and barbed wire. The windows are fitted with bars, handcuffs are in common use, as is body search, while the detainees are dispossessed of their belongings and moved about using prisoner transport vehicles. The sense of punishment, powerlessness and helplessness resulting from the disrespectful and hostile treatment by immigration officials ${ }^{9}$ make for a shocking flashback to what the migrants had experienced in the country they fled. ${ }^{10}$ Other factors contributing to the detrimental effect of detention include its length, overcrowding, lack of constructive activities to occupy detainees, limited access to open air, difficulties in communication with staff and with other detainees, and lack of information about one's situation. ${ }^{11}$ In this context, it is vital that detainees receive periodic assessments of their physical and mental wellbeing even where they presented no worrying symptoms upon arrival. ${ }^{12}$ According to the Special Rapporteur on on torture and other cruel, inhuman or degrading treatment or punishment, ${ }^{13}$ the detention of children who

against Children, Geneva, Switzerland, 2006, p. 16, para. 62; P. Meuwese, Kids behind bars. A study on Children in conflict with the Law: Towards Investing in Prevention, Stopping Incarceration and Meeting International Standards, Defence for Children International, Amsterdam 2003.

8 See Mubilanzila Mayeka and Kaniki Mitunga v. Belgium, para. 55; Human Rights Committee, General Comment No. 35, CCPR/C/GC/35, 16.12.2014, para. 18; D. and E. v. Australia, Communication 1050/2002, U.N. Doc., CCPR/C/87/D/1050/2002, Human Rights Committee Views of 11.7.2006, para. 7.2; Jalloh v. The Netherlands, Communication 794/1998, CCPR/C/74/D/794/1998, Human Rights Committee Views of 26.3.2002, paras. 8.2-8.8.

9 The Report to the Maltese Government on the visit to Malta carried out by the European Committee for the Prevention of Torture and Inhuman or Degrading Treatment or Punishment (CPT) from 26 to 30 September 2011, published on 4.7.2013, para. 48.

10 See the report by Ekaterina Lemondżawa from the Polish guarded centre for foreigners in Lesznowola, of 26.10.2012, http://wyborcza.pl/1,76842,12741561,Gruzinska_ dziennikarka__Opowiem_calej_Europie_o_polskim.html (accessed: 21.3.2020).

11 See Mahamed Jama v. Malta, para. 26; K. Robjant, R. Hassan, C. Katona, Mental health implications of detaining asylum seekers: systematic review, 'British Journal of Psychiatry' 2009, vol. 194, p. 306-312.

12 UNHCR, Guidelines on Applicable Criteria and Standards relating to the Detention of Asylum Seekers, p. 30, para. 48 (vi).

13 Report of the Special Rapporteur on torture and other cruel, inhuman or degrading treatment or punishment - Juan Mendez, A/HRC/28/68, 5.3.2015, para. 80. 
migrate to escape exploitation and abuse contravenes the duty of the State to promote the physical and psychological recovery of child victims in an appropriate environment (Article 34 and Article 39 - Convention on the Rights of the Child). ${ }^{14}$

It needs to be emphasized that the well-being of child migrants is strongly determined by the well-being of their parents and guardians. As their lives become subject to strict regulation at the detention centre, many adult immigrants become unable to provide their children with adequate care, attention and support. ${ }^{15}$ At the same time, it adds to children's psychological damage caused by confinement to see their parents in situations where they are submitted to the guards' will, making them helpless and humiliated. As well as having a clear detrimental effect on children's relationship with their parents, this invariably damages their sense of security. ${ }^{16}$

\section{Right to be a child and subjectivity in migration procedures}

There is a wide consensus, based on the wording of Article $37 \mathrm{CRC}$, that detention of migrant children should be used only as a measure of last resort. ${ }^{17}$ In practical terms, meeting this standard is related to and made

14 UN General Assembly, Convention on the Rights of the Child, 20.11.1989, United Nations, Treaty Series, vol. 1577, p. 3.

15 See Popov v. France, Application no. 39472/07, 39474/07, ECtHR Judgment of 19.1.2012, para. 101; See National Inquiry into Children in immigration Detention 2014, a submission by the Australian Psychological Society to the Australian Human Rights Commission, June 2014, https://www.psychology.org.au/Assets/Files/2014APS-Submission-Children-in-Immigration-Detention-7..pdf, at p. 7 and 9 (accessed: 17.8.2015); Z. Steel, S. Momartin, C. Bateman, A. Hafshejani, D.M. Silove, Psychiatric status of asylum seeker families held for a protracted period in a remote detention centre in Australia, 'Australian and New Zealand Journal of Public Health' 2004, vol. 28 no. 6, p. 532 -535; G. Triggs, Mental Health and Immigration Detention, 'The Medical Journal of Australia' 2013, vol. 199, no. 11, p. 721-722.

16 See J. Burnet et al., State sponsored cruelty. Children in immigration detention, p. 5255, http://www.statewatch.org/news/2010/sep/uk-medical-justice-state-sponsoredcruelty-report.pdf (accessed: 17.8.2015).

17 See Rahimi v. Greece, para. 108. For a more detailed and comprehensive reference to Article $37 \mathrm{~b}$ of the CRC, see G. Van Buerren, The International Law on The Rights of the Child, The Hague-Boston-London 1998, p. 206-215. 
conditional upon respecting the right of all persons under 18 years of age to be recognised as children in migration procedures, as well as allowing them to enjoy this status. Accordingly, children born in the place of confinement should be registered immediately after birth and issued a birth certificate. ${ }^{18}$ Another aspect of practical access to birth registration is to ensure that migrants in an irregular situation should be able to register the birth and should be able to obtain a birth certificate for their children without risk of apprehension. ${ }^{19}$ Moreover, states ought to respect the right of children born to non-citizen parents to acquire the nationality of the state they were born in. ${ }^{20}$ When addressing such persons, the state needs to observe three basic principles: acting in the best interests of the child, ensuring respect for family unity, and applying the principle of non-detention of child migrants. ${ }^{21}$ In this case, the child's best interests demand they be treated as children before they are treated as migrants. ${ }^{22}$

The European Court of Human Rights (ECtHR, 'the Court') established that states' interest in foiling attempts to circumvent immigration rules must not deprive foreign minors, especially if unaccompanied, of the protection their status warrants. ${ }^{23}$ This requires the state to prioritise the child's

18 Article 7(1) CRC and Article 24(2) ICCPR. See also UNHCR ExCom, Conclusion on Refugee Children, No. 47 (XXXVIII) - 1987, paras. (f) and (g), available at: http://www. unhcr.org/refworld/docid/3ae68c432c.html; UN Human Rights Council, Resolution on Rights of the Child, 20.3.2012, A/HRC/19/L.31, para. 16(c) and 29-31, available at: http:// www.unhcr.org/refworld/docid/502e10f42.html; UN Human Rights Council, Resolution on Action on Birth Registration and the Right of Everyone to Recognition Everywhere as a Person Before the Law, 15.3.2012, A/HRC/19/L.24, available at: http://aat p.ohchr. org/documents/dpage_e.aspx?si=A/HRC/19/L.24.

19 Commission Recommendation (EU) 2017/2338 of 16.11.2017 establishing a common 'Return Handbook' to be used by Member States' competent authorities when carrying out return-related tasks, OJ L 339, 19.12.2017, p. 83, para. 5, p. 101.

20 Concluding observations of the Committee of the Rights of the Child: Iceland CRC/C/15/Add.203, 2003, para. 23. At minimum, children of asylum-seekers should not be separated from their parents during detention; Concluding observations of the Committee of the Rights of the Child: Lebanon, CRC/C/15/Add.169, 2002, para. 52, cited in E/CN.4/Sub.2/2002/25/Add.1, para. 67.

21 See P. Ceriani Cernadas, The Human Rights of Children in the Context of International Migration, [in:] W. Vandenhole, E. Desmet (eds.), 'Routledge International Handbook of Children's Rights Studies', Routledge Taylor and Francis Group, London-New York 2015, p. 346.

${ }^{22}$ See M.-B. Dembour, When Humans Become Migrants. Study of the European Court of Human Rights with an Inter-American Counterpoint, Oxford University Press, Oxford 2015, p. 387-388.

${ }^{23}$ See Mubilanzila Mayeka and Kaniki Mitunga v. Belgium, para. 81. 
need for protection and care over the administrative measures aimed at securing the state's interest. This is all the more important in the case of unaccompanied children. ${ }^{24}$ Additionally, children seeking international protection are covered by Article 22 of the CRC, which provides that such children receive appropriate protection and humanitarian assistance in the enjoyment of applicable rights set forth in the Convention and in other international human rights or humanitarian instruments. ${ }^{25}$

An issue that is of special consideration for the problem under discussion is that of age assessment procedures. On the one hand, these constitute the legitimate aim of detention, ${ }^{26}$ and on the other - their outcome is of key importance for evaluating the admissibility of further detention. In this case, the best interests of the child worded in Article 3 $\mathrm{CRC}$ have a multi-faceted manifestation. First, age assessment procedures should only be instituted when there is doubt as to the foreigner's age. These testings should be limited to cases when serious doubt about child's age exist and are to be used as a measure of a last resort. ${ }^{27}$ Second, such foreigners ought to be assumed to be minors unless proven otherwise. Third, age assessment must be multidimensional, ${ }^{28}$ with the reservation that medical examination is only employed when other assessment methods have been exhausted. ${ }^{29}$ It follows that primary consideration should be given to the migrant's documents, especially that the currently

24 UNHCR Guidelines on Policies and Procedures in dealing with Unaccompanied Children Seeking Asylum, February 1997, (hereinafter: 'Guidelines on Unaccompanied Children Seeking Asylum'), para. 7.7. See also Article 24(1) ICCPR: Every child shall have, without any discrimination as to race, colour, sex, language, religion, national or social origin, property or birth, the right to such measures of protection as are required by his status as a minor, on the part of his family, society and the State.

${ }_{25}$ Abdullahi Elmi and Aweys Abubakar v. Malta, Application no 25794/13 and 28151/13 22, ECHR Judgment of 22.11.2016, para. 103.

26 See Mahamed Jama v. Malta, para. 144; Abdullahi Elmi and Aweys Abubakar v. Malta, para. 146.

27 United Nations Children's Fund, Age Assessment: A technical note, 2013, p. 13. See also: Council of Europe Parliamentary Assembly, Unaccompanied Children in Europe: Issues of arrival, stay and return, Resolution 1810(2011), 15.4.2011, para. 5.10.

${ }_{28}$ Committee on the Rights of the Child, General Comment No. 6: Treatment of Unaccompanied and Separated Children Outside their Country of Origin, 1.9.2005, CRC/ GC/2005/6.

29 Directive 2013/32/EU of the European Parliament and of the Council of 26 June 2013 on common procedures for granting and withdrawing international protection (recast), OJ L 180, 29.6.2013, p. 60, Article 25(5). 
used medical procedures are of an invasive character, as well as carrying a considerable margin of error. ${ }^{30}$ The European Committee of Social Rights found that the wide-spread practice of use of bone testing to determine age of unaccompanied foreign minors in France is inappropriate and unreliable, and, therefore, violates Article 17(1) of the Revised European Social Charter. ${ }^{31}$ Similarly, the Committee on the Rights of the Child, expressed concern about the 'overreliance on bone tests to determine the age of children' and encouraged the French government to 'put an end to the use of bone tests as the main method to determine the age of children. ${ }^{32}$ In this context it is important to note that, inadequate or faulty assessment put children at risk of being detained in unsuitable detention facilities and consequently exposed to greater risks of abuse and violence. Moreover, it should also be considered that in a situation of doubt about a person's age, the risks connected with the wrongful detention of the child with unrelated adults is considered higher than the potential damages resulting from a young adult placed in children's accommodation. ${ }^{33}$

States are also called upon to ensure that age assessment is conducted by independent, qualified practitioners and experts and with due respect for the child's rights and physical integrity, and for human dignity. ${ }^{34}$ It is worth mentioning that the European Court of Human Rights underlines the importance of obtaining the informed consent of the child and his or her legal representative prior to referring the child to any medical

30 European Asylum Support Office, Age assessment practice in Europe, December 2013, p. 6; see also: Separated Children in Europe Program, Position Paper on Age Assessment in the Context of Separated Children in Europe, 2012.

31 See European Committee for Home-Based Priority Action for the Child and the Family (EUROCEF) v. France, Complaint No. 114/2015, European Committee of Social Rights Decision of 24.1.2018, para. 113. The Revised European Social Charter, European Treaty Series No. 163, Strasbourg, 3.5.1996.

32 See Human Rights Committee, Concluding observations on the fifth periodic report of France, CRC/C/FRA/CO/5, 23.2.2016, para. $74 \mathrm{~b}$.

${ }_{33}$ Council of Europe, Committee of the Parties to the Council of Europe Convention on the protection of children against sexual exploitation and sexual abuse, Special report: Protecting children affected by the refugee crisis from sexual exploitation and sexual abuse, 13.3.2017, p. 34; Council of Europe, Group of Experts on Action against Trafficking in Human Beings, 6th General Report on GRETA's Activities, March 2017, p. 52.

34 See European Parliament resolution of 12.9.2013 on the situation of unaccompanied minors in the EU (2012/2263(INI)), OJ C 93, 9.3.2016, p. 165. 
examination. ${ }^{35}$ However, it must be pointed out that many migrants find themselves in a situation of little choice, as their refusal to undergo medical examination is often taken as grounds for treating them as adults. ${ }^{36}$

One way to observe children's rights is to provide them with information about these procedures and how they are carried out, including information about their right to appeal. This may be of particular value given that these children may be very much interested in having their status finally determined. ${ }^{37}$ With respect to minors close to adulthood, the Court established that if an applicant of 17 years and 10 months of age failed to apply for registration as a minor, providing only their year of birth to the authorities, the holding state was under no obligation to launch such an application on its own initiative. ${ }^{38}$

If all the procedures fail to establish the foreigner's age, that person should always be given the benefit of the doubt and treated as a minor. ${ }^{39}$ Practice has shown most complications to be caused when assessing the state's actions ex post, when a given migrant has eventually been established to be in fact an adult. In such cases, the ECtHR finds that the evaluation of these actions should be based on the general principles for dealing with adult migrants, rather than applying the rights of the child standards. ${ }^{40}$ Worth considering at this point is the case of Mahamed Jama v. Malta, relating to detention of a person seeking international protection. The applicant claimed to be 16 years old, although she had admitted to being 10 years older upon earlier registration. The applicant was initially held in a part of a detention facility used for accommodating families with children, only to be later moved to a part used for detaining

35 Yazgül Yilmaz v. Turkey, Application No. 36369/06, ECtHR Judgment of 1.2.2011, para. 47.

36 See reasoning of ECtHR in the case Ahmade v. Greece, Application no. 50520/09, ECtHR Judgment of 25.9.2012, para. 78. See for example Act of 12.12.2013 on foreigners, consolidated text: Polish OJ 2018, item 2094 with later changes, Article 397 (5): A foreigner who claims to be a minor and refuses to undergo a medical examination shall be considered an adult.

37 Mahamed Jama v. Malta, para. 41-45.

38 Aarabi v. Greece, Application no. 39766/09, ECHR Judgment of 2.4.2015, para. 43-45.

39 Committee on the Rights of the Child, General Comment No. 6 (2005), at para. 3; UNHCR's guidelines on international protection relating to child protection claims under the 1951 Refugee Convention and its 1967 Protocol, UNHCR No. 8, para. 75; Directive 2013/32/EU Article 25(5).

40 Mahamed Jama, para. 149; Ahmade v. Greece, para. 79. 
minors. ${ }^{41}$ Two weeks after her asylum claim was verified in her favour and she was granted subsidiary protection, the applicant was released from detention. The ECtHR has assessed the two periods of detention for compliance with Article 5(1)(f) of the European Convention on Human Rights and Fundamental Freedoms $(\mathrm{ECHR})^{42}$, drawing the dividing line at the date the applicant was granted international protection. In the first of these, key importance was attached to the state acting in good faith with respect to the length of age determination. Mahamed Jama was detained for a period of over eight months, while it took around seven months to determine her age. ECtHR pointed out that the government was unable to explain why it had been necessary for the applicant to wait two months for her first age assessment interview and a further two months to perform an X-ray on her wrist, which was followed by more than three months that the authorities needed to reach a final decision. Against this backdrop one might be understandably surprised at the Court's conclusion that there had been no violation of Article 5(1)(f) of the ECHR, finding that the applicant's detention for a total of around eight months was in fact closely connected to the purpose of preventing an unauthorised entry, as well being not unreasonable for the purpose pursued. ${ }^{43}$ This was adjudicated, the Court was careful to underline, despite it having serious doubts as to the validity of the arguments put forward by the Maltese government. The applicant turned out to be an adult who misled the state authorities, for which reason the Court examining the situation could not, and indeed did not want to, invoke the CRC. Still, adopting the perspective expressed in the CRC, one could only argue that Mahamed Jama should have been considered a child, and, therefore, been treated as a child until the age assessment procedure proved otherwise. Should children be exposed to waiting seven months for having their status determined? The Maltese government argued such

41 The applicant complained about the conditions of her detention which made the Court examine a potential violation of Article 3 ECHR, eventually recognising this had not been the case. Nevertheless, one might be forgiven for wondering whether the reported conditions, including lack of heating and closed shoes in winter, were not in fact in breach of this provision - see Partly dissenting opinion of Judge Casadevall.

42 European Convention for the Protection of Human Rights and Fundamental Freedoms, as amended by Protocols Nos. 11 and 14, 4.11.1950, European Treaty Series 5, Polish OJ 1993, no. 61, item 284, as amended.

43 Mahamed Jama v. Malta, para. 151-153. However, the Court found a violation Article 5(1) f in respect of the second period of detention after the date of decision of granting of international protection. 
prolonged waiting periods only apply to individuals close to adulthood. ${ }^{44}$ This, however, means that teenagers seeking international protection, who usually cross borders unaccompanied, are subjected to several months' time of detention to allow for their age to be determined. This issue was subjected to ECtHR assessment in case Abdullahi Elmiand Aweys Abubakar v. Malta. According to the Court, even accepting that the detention was closely connected to the ground of detention relied on, namely to prevent an unauthorised entry, the delays in to the determination of the applicants' age, raise serious doubts as to the authorities' good faith. ${ }^{45}$

\section{Right to liberty and security}

Under Article 37(b) of the CRC, states are to ensure that no child is deprived of his or her liberty unlawfully or arbitrarily. Moreover, the arrest, detention or imprisonment of a child should be in conformity with the law and shall be used only as a measure of last resort, and for the shortest appropriate period of time. This provision is taken as the basis for setting out the standards of international refugee law with respect to child detention, ${ }^{46}$ as well as being a point of reference for case-law on international protection of human rights.

In the universal system, immigration detention is subject to the general safeguards of liberty and security of person included in Article 9 International Covenant on Civil and Political Rights ${ }^{47}$ (ICCPR), whereas in the European system, it is subject to Article 5(1)(f) of the (ECHR), which provides for 'the lawful arrest or detention of a person to prevent his effecting an unauthorised entry into the country or of a person against whom action is being taken with a view to deportation or extradition'.

44 Mahamed Jama, para. 148.

45 The first applicant had to wait for a few weeks for his first age-assessment interview and to wait for around seven months to have a decision following a standard medical test. The second applicant had to wait for five months to have the FAV test and to wait for another two and a half months for such a decision, and, therefore, for his release under a care order.

46 See UNHCR, Detention Guidelines, p. 16-18; Guidelines on Unaccompanied Children Seeking Asylum, para. 9.8.

47 Adopted and opened for signature, ratification and accession by General Assembly resolution 2200A (XXI) of 16.12.1966, United Nations, Treaty Series, vol. 999, p. 171 and vol. 1057, p. 407. 
Analysing this regulation, the ECtHR established that holding foreigners in detention centres is only acceptable in cases of illegal migration, and that this detention must, at the same time, comply with the international commitments arising from both the ECHR and the CRC. ${ }^{48}$

The text of Article 37(b) of the CRC overlaps with Article 9 of the ICCPR and Article 5 of the ECHR with respect to the requirement for detention to be lawful and non-arbitrary. Both the Human Rights Committee (HRC) and the ECtHR interpret the lawfulness of this measure in connection with the guarantees under international law that are provided for in the ICCPR and the ECHR. ${ }^{49}$ When it is used to detain children, the measure is additionally verified against the principle of the best interest of the child and Article 37 of the CRC. ${ }^{50}$ At the same time, the law is expected to be precise enough to avoid its arbitrary or excessively broad application. ${ }^{51}$ The Court recognises that rather than merely referring back to the expressions typical of the limiting clauses contained in Articles 8 to 11 of the ECHR, the quality of the law must be compatible with the rule of law, which is a concept inherent in all the Articles of the Convention. ${ }^{52}$ In connection to this, national law and state authorities are required to ensure that deprivation of liberty is sufficiently accessible, precise and foreseeable in its application, in order to avoid all risk of arbitrariness. ${ }^{53}$ According to the Court, the fact that detention comes within paragraph (f) of Article 5(1) of the Convention does not necessarily mean that it is lawful within

48 In particular, the Court considered Articles 3, 10, 22, and 37(b) of the CRC.

49 For example, absence of a court decision on the lawfulness of detention, which is required under Article 9(4) of the ICCPR, was considered to be an element in the unlawful detention of applicants in the case of Shams et al. v. Australia, Communication 1255/2004, CCPR/C/90/D/1255, Human Rights Committee Views of 11.9.2007, para. 7.3. See also Yklymova v. Turkmenistan, Communication 1460/2006, CCPR/C/96/D/1460/2006, Human Rights Committee Views of 20.7.2009, para. 7.4; Aboussedra v. Libyan Arab Jamahiriya, Communication 1751/2008, CCPR/C/100/1751/2008, Human Rights Committee Views of 2.11.2010, para. 7.6.

50 See Rahimi v. Greece, para. 108; Mubilanzila Mayeka and Kaniki Mitunga v. Belgium, para. 83.

51 In particular, the HRC pointed out the excessively broad and ambiguous scope of the notions of national security, terrorism and extremist activity. See Concluding observations: Sudan 1998, para. 124; Mauritius 2005, para. 12; the Russian Federations 2010, para. 25; Tanzania 2009, para. 12.

52 K. v. Russia, Application no. 69235/11, ECtHR Judgment of 23.5.2013, para. 82.

53 See K. v Russia, para. 82; Nolan and K. v. Russia, Application no 2512/04, ECtHR Judgment of 12.2.2009, para. 98. 
the meaning of this provision, as it is required that some relationship exists between the ground of permitted deprivation of liberty relied on and the place and conditions of detention. ${ }^{54}$

In light of Article 9 of the ICCPR, 'arbitrariness' should not merely be equated with being against the law, but must be interpreted more broadly to include elements of inappropriateness, injustice and lack of predictability. ${ }^{55}$ Although the text of the ICCPR does not enumerate permitted exceptions, detention in the course of migration control proceedings is not per se arbitrary. However, detention must be justified as reasonable, necessary, and proportionate in light of the circumstances and reassessed as it extends in time. ${ }^{56}$

The requirement laid down in Article 37(b) of the CRC to use the detention of a child only as a measure of last resort is, so to speak, incorporated and strongly pronounced in the case-law of the HRC and the ECtHR, as well as being reflected in Article 17(1) Return Directive ${ }^{57}$ Articles 11(2) and 11(3) of the recast Reception Conditions Directive. ${ }^{58}$ In Polish law, under Article 88(3)(3) of the amended Act on granting

54 Mubilanzila Mayeka and Kaniki Mitunga v. Belgium, para. 102; Popov v. France, para. 118; Rahimi v. Greece, para. 110; Muskhadzhiyeva and others v. Belgium, para. 73.

${ }_{55}$ See Van Alphen v. The Netherlands, Communication 305/1988, CCPR/ C/39/D/305/1988, Human Rights Committee Views of 23.07.1990, para. 5.8.

56 F.K.A.G. et al. v. Australia, Communication 2094/2011, CCPR/C/108/D/2094/2011, Human Rights Committee Views of 20.8.2013, para. 9.3.

57 Article 17 (1) 'Unaccompanied minors and families with minors shall only be detained as a measure of last resort and for the shortest appropriate period of time'. Directive 2008/115/EC of the European Parliament and of the Council of 16.12.2008 on common standards and procedures in Member States for returning illegally staying third-country nationals OJ L 348, 24.12.2008; additionally, it must be mentioned, that the rule of using detention as a measure of last resort to all migrants in irregular situations is worded in Article 15 of this Directive.

58 Article 11(2): 'Minors shall be detained only as a measure of last resort and after it having been established that other less coercive alternative measures cannot be applied effectively. Such detention shall be for the shortest period of time and all efforts shall be made to release the detained minors and place them in accommodation suitable for minors'; Article 11(3): 'Unaccompanied minors shall be detained only in exceptional circumstances. [No mention has been made of the condition for it having to be established that other less coercive alternative measures cannot be applied effectively.] All efforts shall be made to release the detained unaccompanied minor as soon as possible. Unaccompanied minors shall never be detained in prison accommodation (...) Where unaccompanied minors are detained, Member States shall ensure that they are accommodated separately from adults'. 
protection to foreigners within the territory of the Republic of Poland unaccompanied minors are no longer detained in guarded centres. ${ }^{59}$ In General Comment No. 35, the HRC argued,

Children should not be deprived of liberty, except as a measure of last resort and for the shortest appropriate period of time, taking into account their best interests as a primary consideration with regard to the duration and conditions of detention, and also taking into account the extreme vulnerability and need for care of unaccompanied minors. ${ }^{60}$

In the opinion of the HRC, detention may be considered arbitrary if the state fails to prove it could not enforce its immigration policy by relying on more lenient measures. ${ }^{61}$ As it points out, the state needs first to consider the less invasive means of achieving the same ends, including the imposition of reporting obligations, sureties or other conditions that prevent the individual from absconding. ${ }^{62}$

As a rule, the ECtHR adopts a narrower definition of arbitrariness, demanding it is carried out in good faith, ${ }^{63}$ is closely connected to the ground of detention relied on by the state, and that the length of the detention does not exceed that reasonably required for the purpose pursued. ${ }^{64}$ In cases of the detention of children, the Court introduces a necessity test. It is important to note that two axes exist for identifying child detention as necessary within the ECHR system: the first is grounded in Article 5(1) (f), which gives the basis for determining whether it is in accordance with

59 Act on granting protection to foreigners within the territory of the Republic of Poland of 13.6.2003, consolidated text: Polish OJ 2018, item 1109 with later changes.

60 Human Rights Committee, General Comment No. 35, p. 6.

61 See C. v. Australia, Communication 900/1999, CCPR/C/76/D/900/1999, Human Rights Committee Views of 28.10.2002; Sharif Baban v. Australia, Communication 1014/2001, CCPR/C/78/D/1014/2001, Human Rights Committee Views of 18.9.2003.

62 Sharif Baban v. Australia, para. 7.2; Bakhtiyari v. Australia, Communication 1069/2002, CCPR/C/79/D/1069/2002, Human Rights Committee Views of 29.10.2003, paras. 9.2-9.3; Concluding observations of Human Rights Committee: Belgium 1999, para. 84; Canada 2006, para. 14; Bosnia and Herzegovina 2012, para. 14.

63 See reasoning in Saadi v. the United Kingdom, Application no 13229/03, ECtHR Judgment of 29.1.2008, para. 74.

64 See Mahamed Jamav. Malta, para. 140; see also A. and Others v. the United Kingdom [GC], Application no. 3455/05, ECtHR Judgment of 19.2.2009, para. 164; Louled Massoud v. Malta, Application No. 24340/08, ECtHR Judgment of 27.10.2010, para. 62. 
law, ${ }^{65}$ while the second is the determination whether the interference with the right to private and family life is indeed necessary and proportionate. On examining the standards that require the detention of minors to be necessary, the ECtHR gives overriding importance to the best interest of the child ${ }^{66}$ This makes the state obliged to give priority to the interests of the child, ${ }^{67}$ which entails examining the child's particular situation and verifying that placing him or her in administrative detention is a measure of last resort for which no alternative is available. ${ }^{68}$ The Court argues that an absence of these elements make it questionable whether the state does indeed act in good faith. ${ }^{69}$

At the same time, it must be emphasized that using detention as an ultima ratio measure is the absolutely minimum standard when taking into account the views of some international bodies, that immigration detention is never ever in the best interest of the child. It should be mentioned, that according to the Inter-American Court of Human Rights ${ }^{70}$ and Special Rapporteur on torture and other cruel, inhuman or degrading treatment or punishment, the deprivation of liberty of children based exclusively on immigration-related reasons exceeds the requirement of necessity. ${ }^{71}$ It has been postulated in soft-law documents, that unaccompanied children should never be deprived of their liberty for reasons of migration status. ${ }^{72}$

65 See also UNHCR's Detention Guidelines, Guideline 3.

66 See Rahimi v. Greece, para. 108; Mubilanzila Mayeka and Kaniki Mitunga v. Belgium, para. 83.

67 See Rahimi v. Greece, para. 109.

68 See Popov v. France, para. 119. Importantly to note, the Court found no violation of this provision with respect to the parents who had been detained along with their children - para. 120; A.B. and others v. France, Application no 11593/12, ECtHR Judgment of 12.7.2016, para. 122.

69 See Rahimi v. Greece, at para. 109.

70 Rights and guarantees of children in the context of migration and/or in need of international protection, OC-21/14, Advisory Opinion of Inter-American Court of Human Rights of 19.8.2014, at para. 154.

71 Report of the Special Rapporteur on torture and other cruel, inhuman or degrading treatment or punishment - Juan Mendez, A/HRC/28/68, 5.3.2015, para. 80.

72 See Resolution 1810 (2011) of Parliamentary Assembly, Unaccompanied children in Europe: issues on arrival, stay and return, Doc. 12539. Report of the Special Rapporteur, Gabriela Rodriguez Pizarro, E/CN.4/2003/85/, 30.12.2002, p. 20, para. 75(a). 


\section{Detention and the right to respect for private and family life}

Detaining minors invariably involves potential violation of the child's right to respect for private and family life (Article 17 ICCPR, Article 8 ECHR), as well as falling within the scope of the CRC's regulation with respect to family unity (Articles 5, 8 and $16 \mathrm{CRC}$ ) and the child's right not to be separated from their parents against their will (Article 9 CRC). In this context, the HRC considers that, at the very minimum, states should refrain from separating refugee children from their parents. ${ }^{73}$ One issue that has proven particularly complicated is that of detaining a child on account of his or her parent's migration status or as a consequence of their actions. It must be noted here that states often detain children when their parents are deprived of liberty, which is aimed at keeping the family together. Along this line of thinking, the necessity to detain the adult also determines detention of the child, in which case the child's interest is defined as preserving family unity by detaining all its members together. However, developments in international case-law require a different perspective to be taken, one assuming that the automatism in detaining migrant children with their parents on the premise of maintaining family unity violates the principle of the best interests of the child. According to the Committee of Rights of the Child, the detention of a child because of their or their parent's migration status constitutes a child rights violation and always contravenes the principle of the best interests of the child..$^{74}$ This Committee and Committee on the protection of the rights of all migrant workers and members of their families stated that

the need to keep the family together is not a valid reason to justify the deprivation of liberty of a child. When the child's best interests require keeping the family together, the imperative requirement not to deprive the child of liberty extends to the child's parents

73 Concluding observations of the Committee on the Rights of the Child: Lebanon, CRC/C/15/Add.169, 2002, para. 52, cited in E/CN.4/Sub.2/2002/25/Add.1, para. 6.

74 The Committee on the Rights of the Child, Report of the 2012 day of the general discussion on the rights of all children in the context of international migration at para. 78 . See also Report of the Special Rapporteur on torture and other cruel... op. cit., at para. 80. 
and requires the authorities to choose non-custodial solutions for the entire family ${ }^{75}$.

Both Committees are of the view that child and family immigration detention should be prohibited by law and its abolishment ensured in policy and practice ${ }^{76}$. According to the Special Rapporteur on torture and other cruel, inhuman or degrading treatment or punishment, detention of children based on their or their parent's migration status becomes grossly disproportionate and may constitute cruel, inhuman or degrading treatment of migrant children. $^{77}$

Consequently, in cases where detention measures are to be taken against adults travelling with children, the status of these children should take precedence over the migrant status of their adult companions, calling for employing alternative measures first ${ }^{78}$. This is grounded in Article 2 of the $C R C$, which provides that children are to be protected against all forms of discrimination or punishment on the basis of the status, activities, expressed opinions or beliefs' of their parents, legal guardians or family members. An interesting example of treating a child contrary to the spirit of this regulation was the detention by Belgian authorities of a 5-year-old unaccompanied girl in the prison-like Transit Centre no. 127. In this case, the Belgian state invoked an array of circumstances related to a grave violation of migration regulations on the part of the girl's family, which the authorities believed made it somewhat necessary to detain the minor. Having first reiterated the need to give precedence to the status of a child over the irregular status of the minor, the Court considered that a child as young as five cannot bear any responsibility for the actions of adults. ${ }^{79}$

Two different aspects need to be distinguished here: one related to separating the family due to detention, and the other related to destroying the family life in the course of detention. In both these cases, detention

75 Joint general comment No. 4 (2017) of the Committee on the protection of the rights of all migrant workers and members of their families and No. 23 (2017) of the Committee on the rights of the child on state obligations regarding the human rights of children in the context of international migration in countries of origin, transit, destination and return, CMW/C/GC/4-CRC/C/GCl23 from 16.11.2017, para. Ll.

${ }^{76}$ Joint General Comment, para. 12.

77 Report of the Special Rapporteur on torture and other cruel, inhuman or degrading treatment or punishment, para. 80.

${ }^{78}$ Cf. Bistieva and Others v. Poland, Application no 75157/14, ECtHR Judgment of 10.4.2018; Popov v. France, para. 119.

79 See Mubilanzila Mayeka and Kaniki Mitunga v. Belgium, para. 84. 
entails certain interference with the right to respect for private and family life, making it subject to assessment under the limiting clauses provided for in Article 17(2) of the ICCPR and Article 8(2) of the ECHR. Therefore, the primary requirement is that detention is in accordance with the law. ${ }^{80}$ Other elements considered by such an assessment include whether detention is necessary in a democratic society and proportionate to the legitimate aim pursued..$^{81}$ To assess if family separation is proportionate, one needs to consider whether it may exert a strong and direct impact on the child's development and to take account of the psychological and material elements of their right to an adequate standard of living. The effects of separation become more pronounced daily as detention progresses. Where separating the minor from their parents is unavoidable, both the child and the parents are entitled to receive, upon request, essential information concerning the whereabouts of the absent member(s) of the family (Article 9(4) CRC).

There has been a certain development in the Strasbourg case-law on assessing the impact of detention on family life. Initially, in Muskhadzhiyeva and others $v$. Belgium, the allegation of a breach in the right to family life on account of detention conditions and lack of alternative measures being considered was found to be unsubstantiated, rendering the application concerning this matter inadmissible. Back then, the Court merely stated that detention was used against the entire family of a mother and her four children, meaning no separation was involved. This attitude changed in the latter case of Popov v. France, where the complaint about a violation of Article 8 was considered justified, even though it was again a case of detaining a whole family together. Here, and in many later judgments, the Court expressed the view that although the mutual enjoyment by parent and child of each other's company constitutes a fundamental element of family life, ${ }^{82}$ the single fact of keeping the family together is not a guarantee of respect for family life, especially when family members are deprived of their liberty. ${ }^{83}$ In justifying its judgment, the Court

80 Mubilanzila Mayeka and Kaniki Mitunga v. Belgium, para. 75-78.

81 Mubilanzila Mayeka and Kaniki Mitunga v. Belgium, para. 80.

82 See also Olsson v. Sweden (no. 1), Application no. 10465/83, ECtHR Judgment of 24.3.1988, para. 59.

83 Popov v. France, at para. 134; this element was repeated later inter alia in following cases: A.B. and Others v. France, at para. 145; R.K. and Others v. France, Application no. 68264/14, ECtHR Judgment of 12.7.2016, at para. 106; A.M. and Others V. France, Application no. 24587/12, ECtHR Judgment of 12.7.2016, para. 86; R.C. and V.C. v. France, Application no. 76491/14, ECtHR Judgment of 12.7.016, para. 72. 
acknowledged the differential result of their earlier adjudication; however, it also claimed that the development of the Strasbourg case-law brought about the need to adopt another assessment standard. ${ }^{84}$ This, according to the Court means, that the authorities must, in assessing proportionality, take account of the child's best interests set forth in Article 3, the Convention of the Rights of Child.$^{85}$ Explaining its reasoning, the Court claimed the state should take all the necessary measures to refrain, as far as possible, from detaining families with children, as well as effectively safeguarding their right to respect for family life. ${ }^{86}$

The second element making up the assessment of whether a particular case of detention is necessary in a democratic society is that of alternative measures. Specifically, the question must be answered of whether other, less invasive measures could be employed instead of detention, such as placing the child in a special facility or a hotel. The ECtHR has also found a violation of the Convention in that the state failed to revise and reassess the possibility of using such alternative measures later, as detention was already taking place. ${ }^{87}$ It appears significant that in several cases concerning child detention, the states chose to invoke the risk of either the children or their parents seeking to evade the supervision of the state. ${ }^{88}$ However the obligation of individual assessment relating to the risk of the person concerned absconding plays a fundamental role in these situations, and the decision must be based on an individual examination of that person's case. ${ }^{89}$ The same reasoning was presented in a relatively recent judgment Bistieva and Others v. Poland, where the Court ruled that even in the light of the risk that the family might abscond, the authorities failed to provide sufficient reasons to justify the detention for five months and twenty days in a Polish guarded centre in Kętrzyn..$^{90}$ Particularly noteworthy is,

84 See also Rahimi v. Greece, para. 109. R.K. and Others v. France, para. 112.

85 See Popov v. France, para. 140; see Bistieva and Others v. Poland, para. 78; R.K. and Others v. France, para. 106; A.B. and Others v. France, para. 71; R.K. and Others v. France, para. 11; R.C. and V.C. v. France, para. 79.

86 See Popov v. France, para. 134.

87 See Popov v. France, para. 147; Bistieva and Others, para. 86.

88 See Popov v. France, para. 146; Mubilanzila Mayeka and Kaniki Mitunga v. Belgium, para. 83.

${ }^{89}$ Md Sagor, C-430/11, Judgment of 6.12.2012, ECLI: EU:C:2012:777, para. 41; Bashir Mohamed Ali Mahdi, C-146/14 PPU, Judgment of Court of 5.6.2014, ECLI:EU:C:2014:1320, para. 70.

90 Bistieva and Others v. Poland, para. 88. 
that this time, the Court found violation of the Article 8 ECHR in respect to the whole detained family, and not only with respect to children, as it was in the similar earlier cases. ${ }^{91}$

\section{Children's rights with respect to detention conditions}

Conditions of detention must be governed not only by the best interests of the child rule, but also must pay full respect to Article 37(a) and (c) of the Convention and other international obligations. Indeed, the underlying approach to such a program should be 'care' and not 'detention'. Pursuant to Article 37(c) of the CRC, every child deprived of liberty shall be treated with humanity and respect for the inherent dignity of the human person, and in a manner that takes into account the needs of persons of his or her age. ${ }^{92}$ In particular, every child deprived of liberty shall be separated from adults unless it is considered in the child's best interest not to do so, and shall have the right to maintain contact with his or her family through correspondence and visits, save in exceptional circumstances. The exact opposite to this solution, one that is still in pursuance of this regulation and in keeping with the best interests of the child, assumes placing the child in detention along with their parents. This, however, requires the state to develop policies for placing the entire family in alternative locations to closed detention centres. ${ }^{93}$ The UNHCR Guidelines provide that accommodation for families ought to be provided where possible, ${ }^{94}$ while this obligation is regulated in EU legislation by Article 11(4) of the Reception Conditions Directive, which has already been implemented into the Polish law. ${ }^{95}$

91 A.B. and Others v. France, para. 124; Popov v. France, paras. 119-120.

92 See F.K.A.G. et al.v. Australia, para. 9.3.

93 Human Rights Council, Report of Special Rapporteur on the human rights of migrants, Mr. Jorge Bustamante. A/HRC/11/7, 14.05.2009, para. 62; Report of Special Rapporteur on the human rights of migrants, Mr. François Crépeau. A/HRC/20/24, 02.04.2012, para. 40.

${ }^{94}$ Where possible, accommodation for families ought to be provided - UNHCR Detention Guidelines, p. 29.

95 It must be pointed out that under the previous act, families and children were only accommodated together 'as far as possible' - Article 414(3) Act on Foreigners. 
The situation of children as vulnerable subjects also generates positive obligations, requiring the state to ensure children are treated appropriately and provided with adequate detention conditions. ${ }^{96}$ These conditions are assessed from the point of view of children's physical and emotional integrity on the grounds of the prohibition of inhuman or degrading treatment or punishment and the right to respect for private and family life. ${ }^{97}$ It must be pointed out that the Strasbourg case-law has already adopted a standard calling for placing families with children in appropriate conditions that allow for leading a family life despite detention. ${ }^{98}$ Also worth noting is the fact that secondary EU legislation requires the state to provide detained families with separate accommodation guaranteeing adequate privacy. ${ }^{99}$

In extreme cases, the Court has also recognised a breach of the prohibition of torture arising from Article 3 of the ECHR on account of the serious psychological effects that detention has on child asylum-seekers. ${ }^{100}$ In cases concerning the placement of accompanied foreign minors, three factors should be considered: the child's young age, the length of the detention and unsuitability of the premises for the accommodation of children. In Kanagaratnam and others v. Belgium, the Court found there had been a violation of Article 3 of the Convention on the grounds of inadequate and unsuitable detention conditions in which the state placed particularly vulnerable children, whose father had been arrested, forcing them to flee from a war-torn country. ${ }^{101}$ In relation to minors, who were sixteen and seventeen years of age, respectively, and were detained for a period of around eight months, the Court concluded that the cumulative effect of the conditions complained of, amounted to degrading treatment in violation of Article 3 ECHR. There were, inter alia, limited light and ventilation,

96 See E. Manco, Detention of the Child in the Light of International Law: A Commentary on Article 37 of the United Nation Convention on the Rights of the Child, 'Amsterdam Law Forum' 2015, vol. 7.

97 See M. Forowicz, Reception of International Law in the European Court of Human Rights, Oxford University Press, Oxford 2010, p. 126.

98 See Popov v. France, para. 146.

99 See Article 11(4) recast Reception Conditions Directive and Article 17(2) Return Directive. See also Guidelines on Accelerated Asylum Procedures, 'XI. Detention. CPT standards, doc. CPT/Inf (2002) 1 - 2010.

100 See Mubilanzila Mayeka and Kaniki Mitunga v. Belgium, para. 58.

101 See Kanagaratnam and Others v. Belgium, Application no. 15297/09, ECHR Judgment of 13.12.2011, para. 67-69. 
deplorable sanitary facilities, lack of organised (entertainment) activities for minors, lack of proper counselling and educational assistance, a violent atmosphere and a lack of support mechanisms for the minors, as well as lack of information concerning their situation. ${ }^{102}$

Detention centres should, therefore, meet a range of criteria relating to infrastructure, activities provided and qualified staff, as well as being organised in a way taking account of the rights and interests of the child. At the same time, the state ought to consider the differential needs of children in different age groups. ${ }^{103}$ One key element is to provide children with a possibility to play with their peers, as this has been found to be of primary significance in reducing stress and trauma. ${ }^{104}$ It is important, to note the view of the Committee of the Right of Child, that the detention facilities should not be located in isolated areas where culturally-appropriate community resources and access to legal aid are unavailable. ${ }^{105}$ As regards access to education, all child refugees should, first, have access to elementary education irrespective of their status or length of stay; ${ }^{106}$ and second, should be able to attend a school outside the detention premises, in order to make it easier for them to continue education upon release.

\section{Conclusions}

The above considerations lead to the conclusion, that every decision in respect of detention of children in migration context should be grounded on presumption of liberty. The main reason is the undeniable negative impact of stay in detention facilities on a child's health and well-being. There is broad international consensus that this measure should be used as a last resort for the shortest appropriate period of time. Additionally, the state has positive obligation to ensure that children are treated appropriately

102 Abdullahi Elmi and Aweys Abubakar v. Malta, para. 109-115.

103 Concluding observations of the Committee of the Rights of the Child: Czech Republic (CRC/C/15/Add.201), 2003, para. 56, cited in E/CN.4/Sub.2/2003/23/Add.1, para. 48.

104 Guideline 8. See CRC General Comment No. 6: Treatment of Unaccompanied and Separated Children Outside their Country of Origin, above note 103, para. 61.

105 CRC, General Comment no. 6, para. 63.

106 Article 22, 1951 Convention; Article 26 UDHR; Article 13 and 14 ICESCR; Article 28 CRC; Article 10 CEDAW. 
and provided with adequate detention conditions. This obligation results, first of all, from the interpretation of the provisions of the Convention on the Rights of the Child, especially of Article 3 and Article 37. At the same time, there is a rich case law of human rights bodies that implies that unnecessary detention of children even with their parents, without due consideration to possible alternative measures is a violation of their freedom and personal security and the right to private and family life. Herein, length of detention period in combination with age and inadequate conditions could be assessed as a violation of prohibition of torture, cruel inhuman or degrading treatment or punishment.

However, it should be emphasized, that using detention as ultima ratio and refraining from holding unaccompanied or separated children in administrative detention is the absolute minimum. Worth supporting are the views of international bodies that recommend expeditiously and completely ceasing the immigration detention of children with or without their parents. This standard could reinforce the rule for avoiding child detention as it includes acknowledging that detaining minors in connection to their parents' migration status is never in compliance with the principle of the best interest of the child. From this point of view, it is important to pay special attention not only to the content of domestic legislation, but also to practical application of in-place regulations. Furthermore, in this context, it is significant to develop practical availability of alternatives to detention, where children can remain with their families or guardians in non-custodial conditions.

\section{Bibliography}

1. Burnet J. et al., State sponsored cruelty. Children in immigration detention, http://www.statewatch.org/news/2010/sep/uk-medical-justice-statesponsored-cruelty-report.pdf (accessed: 17.8.2015)

2. Ceriani Cernadas P., The Human Rights of Children in the Context of International Migration, [in:] Vandenhole W., Desmet E. (eds.) 'Routledge International Handbook of Children's Rights Studies', Routledge Taylor and Francis Group, London-New York 2015

3. Dembour M.-B., When Humans Become Migrants. Study of the European Court of Human Rights with an Inter-American Counterpoint, Oxford University Press, Oxford 2015

4. Forowicz M., Reception of International Law in the European Court of Human Rights, Oxford University Press, Oxford 2010 
5. Manco E., Detention of the Child in the Light of International Law: A Commentary on Article 37 of the United Nation Convention on the Rights of the Child, 'Amsterdam Law Forum' 2015, vol. 7

6. Meuwese P., Kids behind bars. A study on Children in conflict with the Law: Towards Investing in Prevention, Stopping Incarceration and Meeting International Standards, Defence for Children International, Amsterdam 2003

7. National Inquiry into Children in immigration Detention 2014. A submission by the Australian Psychological Society to the Australian Human Rights Commission, June 2014, https://www.psychology.org.au/Assets/Files/2014APS-Submission-Children-in-Immigration-Detention-7.pdf

8. Pinheiro P.S., World Report on violence against children. United Nations Secretary-General's Study on Violence against Children, Geneva, Switzerland, 2006

9. Robjant K., Hassan R., Katona C., Mental health implications of detaining asylum seekers: systematic review, 'British Journal of Psychiatry' 2009, vol. 194

10. Steel Z., Momartin S., Bateman C., Hafshejani A., Silove D.M., Psychiatric status of asylum seeker families held for a protracted period in a remote detention centre in Australia, 'Australian and New Zealand Journal of Public Health' 2004, vol. 28, no. 6

11. Triggs G., Mental Health and Immigration Detention, 'The Medical Journal of Australia' 2013, vol. 199, no. 11

12. Uncounted: The Detention of Migrants and Asylum Seekers in Europe, Global Detention Project, 2015

13. Van Buerren G., The international Law on The Rights of the Child, The HagueBoston-London 1998 